\title{
Fractionation and Long-Term Laboratory Incubation to Measure Soil Organic Matter Dynamics
}

\author{
S. Haile-Mariam \\ Washington State Univ. \\ Irrigated Agricultural Research and Extension \\ Center \\ 24106 N. Bunn Rd. \\ Prosser, WA 99350
}

\section{H. P. Collins* \\ USDA-ARS \\ Vegetable and Forage Research Unit \\ 24106 North Bunn Rd. \\ Prosser, WA 99350}

\section{S. Wright \\ USDA-ARS \\ 10300 Baltimore Ave. \\ Bldg. 001, Room 140 \\ BARC-West \\ Beltsville, MD 20705}

\author{
E. A. Paul \\ Colorado State Univ. \\ Natural Resource Ecology Lab. \\ Fort Collins, $\mathrm{CO}$
}

Soil organic matter (SOM) in agricultural soils comprises a significant part of the global terrestrial $\mathrm{C}$ pool. It has often been characterized by utilizing a combination of chemical dispersion of the soil followed by physical separation. We fractionated soil samples under continuous corn (Zea mays L.) rotations at four long-term sites in the Corn Belt to determine the concentration of $\mathrm{C}$ and $\mathrm{N}$ associated with soil fractions (light fraction [LF], particulate organic matter [POM], silt size, clay size, and Bradford reactive soil protein [BRSP]) and to identify the change in $\mathrm{C}$ concentration and $\delta^{13} \mathrm{C}$ signal of each fraction using laboratory incubations. Light fractions comprised 3 to $5 \%$ of the soil organic carbon (SOC), with no significant difference between conventional tillage (CT) and no-till (NT) treatments. The POM fraction accounted for 5 to $11 \%$ of the SOC in the soils with $>30 \%$ clay and 17 to $23 \%$ for the soils with $<20 \%$ clay. The clay-size fraction contained the highest proportion of SOC. Measurement of ${ }^{13} \mathrm{C}$ during long-term incubation showed that the average mean residence time (MRT) of corn-derived $\mathrm{C}$ in the LF was $3.5 \mathrm{yr}$, whereas the POM fractions ranged from 6 to $12 \mathrm{yr}$. The ${ }^{13} \mathrm{C}$ changes during incubation show that both fractions consist of a mixture of active and resistant materials, with movement between fractions. The BRSP has long MRTs except in the NT Hoytville soil. Measurement of the dyna mics of these fractions provides a basis for $\mathrm{C}$ models to test the impacts of land use and management on $\mathrm{C}$ sequestration.

Abbreviations: BRSP, Bradford reactive soil protein; CT, conventional tillage; KBS, Kellogg Biological Station; LF, light fraction; MRT, mean residence time; NT, no-till; OM, organic matter; POM, particulate organic matter; SOC, soil organic carbon; SOM, soil organic matter.
$S_{a}^{\text {oil }}$ oil organic matter (SOM) in agricultural soils comprises a significant part of the global terrestrial $\mathrm{C}$ and $\mathrm{N}$ pools Agriculture has caused significant reductions in SOM levels in most soils, contributing to increases in atmospheric $\mathrm{CO}_{2}$ levels. Reductions in residue returns to agricultural fields have resulted in poor soil physical conditions, greater risk of soil erosion, poor water retention, and less cycling of nutrients through organic forms. Altered management practices (e.g., reduced tillage, decreased bare fallow, increased residue input, or conversion to native vegetation) can potentially mitigate the loss of SOM and increase soil C and N levels (Paustian et al., 1997; Flach et al., 1997).

Soil organic matter is composed of a continuum of materials ranging in age from days for plant residues and root exu-

Soil Sci. Soc. Am. J. 72:370-378

doi:10.2136/sssaj2007.0126

Received 3 Apr. 2007.

*Corresponding author (hal.collins@ars.usda.gov).

(C) Soil Science Society of America

677 S. Segoe Rd. Madison WI 53711 USA

All rights reserved. No part of this periodical may be reproduced or transmitted in any form or by any means, electronic or mechanical, including photocopying, recording, or any information storage and retrieval system, without permission in writing from the publisher. Permission for printing and for reprinting the material contained herein has been obtained by the publisher. dates to $>1000 \mathrm{yr}$ for the resistant humics (Campbell et al., $1967 \mathrm{a}, 1967 \mathrm{~b})$. Soil ages vary with parent material, landscape position, vegetation, and changes in SOM fractions due to agricultural management. Atmospheric $\mathrm{CO}_{2}$ contains both a long-lived radioactive $\left({ }^{14} \mathrm{C}\right)$ and a stable $\left({ }^{13} \mathrm{C}\right)$ isotope. These are incorporated into plants by photosynthesis and into soils by microbial transformations and humification with little change in the isotopic signal (Boutton, 1996). The majority of soils within the Corn Belt of North America were formed in glacial deposits (till, outwash, or loess overlying glacial till) originating from the Late Wisconsinan glacial drift (ca. 14,500 yr $\mathrm{BP})$. These soils developed under forest in the eastern Corn Belt and prairie vegetation in the west. The switch from $\mathrm{C}_{3}$ forest vegetation to $\mathrm{C}_{4}$ corn is reflected in the change in the ${ }^{13} \mathrm{C}$ content of the soil (Balesdent et al., 1988; Gregorich et al., 1997; Collins et al., 2000). This provides a useful signal for ${ }^{13} \mathrm{C}$ studies in soils representing a range of soil types, parent materials, and climates.

Collins et al. (1999) calculated the turnover of $\mathrm{C}_{3}-$ and $\mathrm{C}_{4}-\mathrm{C}$ residues remaining, in long-term experimental sites, with known $\mathrm{C}$ inputs and management history.

Extended laboratory incubations and curve fitting were used to determine the turnover kinetics $\left(k_{\mathrm{a}}, k_{\mathrm{s}}\right)$ and pool sizes $\left(C_{\mathrm{a}}, C_{\mathrm{s}}\right)$ of the active and slow $\mathrm{C}$ fractions and determine the relative contribution of varying crop residue inputs $\left(\mathrm{C}_{3}, \mathrm{C}_{4}\right)$ to soil organic C (SOC) pools (Collins et al., 2000). They 
reported that during $800 \mathrm{~d}$ of laboratory incubation, the quantity of SOC mineralized ranged from 10.3 to $15.4 \%$ of the total C. It was similar in both conventional tillage (CT) and no-till (NT) treatments for Wooster and Hoytville, $\mathrm{OH}$, soils but was significantly different for soils at the Kellogg Biological Station (KBS). The SOC loss determined by direct measurement of total SOC after $800 \mathrm{~d}$ of incubation indicated a loss ranging from 14 to $21 \%$ in NT and 13 to $19 \%$ in CT. The SOC loss, determined using direct SOC measurement, was higher for NT than for CT treatment sites. The higher SOC loss from NT than CT treatments could be attributed to the initial higher SOC content. A relatively higher SOC loss was observed with direct total soil $\mathrm{C}$ determination than with the $\mathrm{CO}_{2}$ evolution measurement. More of the SOC was lost during the first $440 \mathrm{~d}(8-16 \%)$ than between 440 and $800 \mathrm{~d}$ (29\%) during incubation of these soils.

The SOC is not lost equally from all fractions of the SOM during incubation. This can cause shifts in the relative abundance of $\mathrm{C}$ in the different size and density fractions (HaileMariam et al., 2000). Numerous studies have fractionated SOM by utilizing a combination of chemical dispersion of the soil followed by physical separation. These fractions include a light fraction (LF) consisting of material with a density of $<1.7 \mathrm{~g} \mathrm{~cm}^{-3}$, a particulate organic matter fraction (POM) that is associated with sand-size particles and partially protected fractions within aggregates, and the SOM associated with siltand clay-size particles (Stevenson and Elliott, 1989; Janzen et al., 1992; Beare et al., 1994; Six et al., 1998). Analysis of these fractions using ${ }^{13} \mathrm{C}$ nuclear magnetic resonance spectroscopy indicated that they are chemically different (Sohi et al., 2005). Decomposability of SOC associated with textural fractions decreases in the order of sand, clay, whole soil, and silt in some soils (Christensen, 1987). In others, the coarse clay fraction is the oldest (Campbell et al., 1967a, 1967b). Gregorich et al. (1995), studying eastern Canadian soils, indicated that mineralization of the LF-C $\left(<1.7 \mathrm{~g} \mathrm{~cm}^{-3}\right)$ was more rapid (mean residence time [MRT] $\sim 8 \mathrm{yr}$ ) than that associated with any other particle-size fraction. The organic $\mathrm{C}$ of the LF and sandsized (POM) fractions are mineralized faster than that of the silt- and clay-size fractions (Tiessen and Stewart, 1983; Dalal and Mayer, 1986a, 1986b; Gregorich et al., 1995).

Wright and Upadhyaya (1996) described a hydrophobic, citric-soluble organic component of SOC that reacted with the general Bradford protein reagent. The name glomalin was used to describe this material that has been found to contain high concentrations of $\mathrm{Fe}$ and promote aggregate stability. Glomalin has been found to be co-extracted with other SOC components such as humic acid (Nichols and Wright, 2005; Schindler et al., 2007; Rosier et al., 2006). In this study, we refer to glomalin as Bradford reactive soil protein (BRSP). This BRSP was found to be highly correlated to total soil $\mathrm{C}$ and comprise from 3.8 to $7.8 \%$ of the soil $\mathrm{C}$ depending on land use type and soil depth (Rillig et al., 2003). Incubation has shown the BRSP content to be reduced by $25 \%$ during a 150 -d incubation (Steinberg and Rillig, 2003) and by $50 \%$ in different soils during a 453-d incubation (Rillig et al., 2003)

This study, utilizing the ability of soil enzymes produced by the soil biota during extended laboratory incubation to fractionate the different pools, determined the changes of $\mathrm{C}$ and $\mathrm{N}$ content in SOM fractions. The availability of soils from 440 and $800 \mathrm{~d}$ of incubation from the study by Collins et al. (2000) made it possible to determine the distribution of SOC fractions as the level of whole SOC changed through time. We analyzed soil samples from CT and NT continuous corn rotations at three long-term sites in the Corn Belt and one $\mathrm{N}$ fertilizer experiment in the Corn Belt to: (i) determine the concentration of $\mathrm{C}$ associated with five soil fractions (LF, POM, silt, and clay, as well as citric acid soluble $\mathrm{C}$ that reacts with the Bradford protein assay (BRSP); (ii) identify the change in $\mathrm{C}$ concentration and $\delta^{13} \mathrm{C}$ signal of each fraction during extended laboratory incubations; and (iii) calculate the MRT of those fractions that showed enough changes to produce different ${ }^{13} \mathrm{C}$ contents during incubation.

\section{MATERIALS AND METHODS}

Soils from four long-term agricultural experiment sites in the Corn Belt region of the United States were sampled in 1992 and 1993 (Table 1). The Lamberton, MN, and Wooster and Hoytville, $\mathrm{OH}$, sites had been in continuous corn for at least $30 \mathrm{yr}$. Except for a soybean [Glycine max (L.) Merr.] planting in 1989, the KBS site was under continuous corn cultivation from 1986 until the soils were sampled. The history and description of the sites as well as methods of sampling were described in Collins et al. (1999, 2000). Briefly, longterm rotations (8-33 yr) of conventional tillage (moldboard plow) and conservation tillage (no-till) cropped continuously to corn were used in this study. Six cores $(5.4 \mathrm{~cm})$ to a depth of $1 \mathrm{~m}$ were collected using a truck-mounted hydraulic soil probe and composited for each replicate. Before compositing, each soil core was divided into four depth increments: 0 to 20,20 to 25,25 to 50 , and 50 to $100 \mathrm{~cm}$. Soil samples were sieved moist to pass a $2-\mathrm{mm}$ screen and recognizable plant fragments were removed. Only soil from the 0 - to $20-\mathrm{cm}$ depth increment was analyzed in this study.

Total soil C content was determined with an NCS elemental analyzer (Carlo Erba NA1500 series II, Milan, Italy) and $\delta^{13} \mathrm{C}$ was determined on a Europa mass spectrometer Model 2020 (PDZ Europa, Norwich, UK). Working standards for ${ }^{13} \mathrm{C}$ were sugarbeet (Beta vulgaris L. ssp. vulgaris) sucrose (-25.68\%o V-PDB) and sugarcane (Saccharum officinarum L.) sucrose (-10.45\%o V-PDB). The working standards were calibrated against international standards NBS-22 (-29.74\%o V-PDB) and ANU sucrose (IAEA-C-6,

Table 1. Geographical location, soil series, classification, parent material, particle size, and mean annual temperature by site.

\begin{tabular}{|c|c|c|c|c|c|c|c|c|}
\hline \multirow{2}{*}{ Site } & \multirow{2}{*}{ Geographic location } & \multirow{2}{*}{ Soil series and texture } & \multirow{2}{*}{ Classification } & \multirow{2}{*}{ Parent material } & \multicolumn{3}{|c|}{ Fraction $(<2 \mathrm{~mm})$} & \multirow{2}{*}{ MAT+ } \\
\hline & & & & & Sand & Silt & Clay & \\
\hline & & & & & & $\%$ & & ${ }^{\circ} \mathrm{C}$ \\
\hline Wooster, $\mathrm{OH}$ & $40^{\circ} 48^{\prime} \mathrm{N}, 82^{\circ} 00^{\prime} \mathrm{W}$ & Wooster silt loam & Typic Fragiudalfs & glacial till & 22 & 59 & 19 & 9.1 \\
\hline Hoytville, OH & $41^{\circ} 00^{\prime} \mathrm{N}, 84^{\circ} 00^{\prime} \mathrm{W}$ & Hoytville silty clay loam & Mollic Ochraqualfs & lacustrine & 19 & 31 & 50 & 9.5 \\
\hline Kellogg Biological Stn., MI & $42^{\circ} 18^{\prime} \mathrm{N}, 85^{\circ} 30^{\prime} \mathrm{W}$ & Kalamazoo loam & Typic Hapludalfs & glacial outwash & 43 & 38 & 19 & 9.0 \\
\hline Lamberton, MN & $44^{\circ} 14^{\prime} \mathrm{N}, 95^{\circ} 18^{\prime} \mathrm{W}$ & Normania loam & Typic Haplustolls & glacial till & 33 & 36 & 31 & 6.2 \\
\hline
\end{tabular}

+ Mean annual air temperature. 
$-10.43 \%$ V-PDB). Isotopic ratios are expressed as $\delta^{13} \mathrm{C}$ values, $\delta^{13} \mathrm{C}$ $(\%$ o $)=\left(R_{\text {sample }} / R_{\text {reference }}-1\right) 1000$, where $R={ }^{13} \mathrm{C} /{ }^{12} \mathrm{C}$ (Balesdent and Balabane, 1992).

The LF of the 0 - to 20 -cm depth was determined by adding $10 \mathrm{~g}$ of soil to a $100-\mathrm{mL}$ beaker to which $40 \mathrm{~mL}$ of NaI solution (specific gravity $\sim 1.70 \mathrm{~g} \mathrm{~cm}^{-3}$ ) was added (Janzen et al., 1992). The floating material was ground $(<150 \mu \mathrm{m})$ and analyzed for total $\mathrm{C}$ and $\delta^{13} \mathrm{C}$. After the LF was removed, soil samples were washed three times with $50 \mathrm{~mL}$ of distilled water to remove the $\mathrm{NaI}$, then dispersed in $30 \mathrm{~mL}$ of $5 \mathrm{~g} \mathrm{~L}^{-1} \mathrm{Na}$ hexametaphosphate by shaking for $15 \mathrm{~h}$ on a reciprocal shaker (Cambardella and Elliott, 1992). Following dispersion, samples were passed through a $53-\mu \mathrm{m}$ sieve and rinsed with water to remove silt and clay. The POM plus sand retained on the sieve was dried at $60^{\circ} \mathrm{C}$ overnight. The slurry passing through the sieve was fractionated to silt and clay by sedimentation and decantation. The sand plus POM, silt, and clay were ground to pass a $250-\mu \mathrm{m}$ screen and analyzed for total $\mathrm{C}$ and $\delta^{13} \mathrm{C}$.

Bradford reactive soil protein, also identified as glomalin, was extracted with $50 \mathrm{mmol} \mathrm{L}^{-1}$ citrate, $\mathrm{pH} 8.0$, at $121^{\circ} \mathrm{C}$ for $1 \mathrm{~h}$ (Wright and Upadhyaya, 1996). Samples were centrifuged and the supernatant decanted and saved. The procedure was repeated until the supernatant was straw colored (usually three extractions or more). Supernatants from the sequential extraction were combined and frozen, and $1 \mathrm{~mL}$ subsequently used for the protein assay.

Fractionations of unincubated soils were compared with soil samples following the extended laboratory incubations (440 and $800 \mathrm{~d}$ ) of Collins et al. (2000). Briefly, the extended laboratory incubations were conducted on duplicate $25-\mathrm{g}$, moist-sieved samples from the 0 - to 20 -cm depth increment of each field replicate, adjusted to $60 \%$ of water holding capacity and incubated in $160-\mathrm{mL}$ bottles in the dark at $25^{\circ} \mathrm{C}$.
Headspace $\mathrm{CO}_{2}$ was measured using a Beckman Model 865 infrared gas analyzer (Beckman Instruments, Fullerton, CA) initially at 10-d intervals, then at approximately 21-d intervals after $100 \mathrm{~d}$ of incubation. Following $\mathrm{CO}_{2}$ analysis, each sample was returned to ambient $\mathrm{CO}_{2}$ by degassing with compressed air. After the long-term laboratory incubation, each soil sample was air dried and stored in airtight containers until fractionated in the current study. We analyzed the proportion of $\mathrm{C}$ derived from corn residues for each SOC fractions using the equation: $\mathrm{C}$ derived from corn $(\%)=\left(\delta-\delta_{\mathrm{f}}\right) /\left(\delta_{\text {corn }}\right.$ - $\left.\delta_{\mathrm{f}}\right) 100$, where $\delta=\delta^{13} \mathrm{C}$ values of the SOC fraction or whole soil from corn-cultivated soil, $\delta_{\mathrm{f}}=\delta^{13} \mathrm{C}$ value of the native forest soil, and $\delta_{\text {corn }}=\delta 12.0 \%$ o. The $\delta^{13} \mathrm{C}$ of corn stover was determined for triplicate samples collected across all sites. We estimated the turnover rates of the LF and POM by curve fitting the 0-, 440-, and 800-d LF and POM concentrations to a first-order decay model $C_{t}=C_{0} \exp (-k t)$ using nonlinear regression in SAS (SAS Institute, Cary, NC), where $C_{t}$ is total $\mathrm{C}$ in the fraction at time $t, C_{0}$ is the initial $\mathrm{C}$ content, and MRT is the reciprocal $\left(k^{-1}\right)$ of the decomposition rate constant, $k$.

\section{RESULTS AND DISCUSSION \\ Soil Organic Carbon Fractions in Conventional Tillage and No-Till Soils}

The distribution of SOC in the LF, POM, and silt- and clay-size fractions varied among sites and was dependent on the SOC content and soil particle size distribution. Light fractions separated using a density of $1.7 \mathrm{~g} \mathrm{~cm}^{-3}$ at time zero before incubation had SOC contents ranging from 0.5 to $0.8 \mathrm{~g} \mathrm{C} \mathrm{kg}^{-1}$ and accounted for 3 to $5 \%$ of the SOC with no significant difference between CT and NT treatments (Table 2). Skjemstad et al. (1986) reported that the LF in a cultivated soil accounted for $1 \%$ of the total SOC and Tiessen and Stewart (1983) found

Table 2. Organic $C$ distribution among light fraction (LF), particulate organic matter (POM), silt, and clay soil fractions, soluble $C$, and the whole soil during long-term incubation of the Wooster and Hoytville, $\mathrm{OH}$, and Kellogg Biological Station (KBS), MI, soils by absolute content (Abs.) and proportion (Prop.).

\begin{tabular}{|c|c|c|c|c|c|c|c|c|c|c|c|c|}
\hline \multirow{3}{*}{ Soil fraction } & \multicolumn{6}{|c|}{ Conventional tillage } & \multicolumn{6}{|c|}{ No-till } \\
\hline & \multicolumn{2}{|c|}{ Wooster, $\mathrm{OH}$} & \multicolumn{2}{|c|}{ Hoytville, $\mathrm{OH}$} & \multicolumn{2}{|c|}{ KBS, MI } & \multicolumn{2}{|c|}{ Wooster, $\mathrm{OH}$} & \multicolumn{2}{|c|}{ Hoytville, OH } & \multicolumn{2}{|c|}{ KBS, MI } \\
\hline & Abs. & Prop. & Abs. & Prop. & Abs. & Prop. & Abs. & Prop. & Abs. & Prop. & Abs. & Prop. \\
\hline & $\mathrm{g} \mathrm{C} \mathrm{kg}^{-1}$ & $\%$ & $\mathrm{~g} \mathrm{C} \mathrm{kg}^{-1}$ & $\%$ & $\mathrm{~g} \mathrm{C} \mathrm{kg}^{-1}$ & $\%$ & $\mathrm{~g} \mathrm{C} \mathrm{kgl}^{-1}$ & $\%$ & $\mathrm{~g} \mathrm{C} \mathrm{kg}^{-1}$ & $\%$ & $\mathrm{~g} \mathrm{C} \mathrm{kg}^{-1}$ & $\%$ \\
\hline LF & $0.6(0.1) \dagger$ & 5.4 & $0.7(0.2)$ & 3.5 & $0.5(0.1)$ & 4.5 & $0.6(0.1)$ & 3.6 & $0.8(0.2)$ & 3.0 & $0.6(0.1)$ & 4.6 \\
\hline POM + sand & $2.2(0.1)$ & 20.6 & $2.1(0.8)$ & 11.0 & $2.2(0.3)$ & 20.4 & $3.6(0.2)$ & 22.9 & $2.2(0.2)$ & 8.4 & $2.0(0.3)$ & 17.4 \\
\hline Silt & $3.0(0.1)$ & 28.5 & $4.4(0.8)$ & 23.1 & $1.9(0.2)$ & 17.5 & $4.3(0.4)$ & 27.4 & $4.7(0.5)$ & 18.4 & $2.0(0.1)$ & 17.6 \\
\hline Clay & $3.8(0.1)$ & 35.7 & $10.1(4.6)$ & 52.9 & $5.3(0.1)$ & 48.5 & $5.6(0.8)$ & 36.3 & $15.5(0.2)$ & 60.6 & $5.8(0.3)$ & 50.6 \\
\hline Soluble C‡ & $1.0 \S$ & 10.0 & $1.8 \S$ & 9.5 & $1.0 \S$ & 9.3 & $1.5 \S$ & 9.5 & $2.4 \S$ & 9.6 & $1.1 \S$ & 9.7 \\
\hline Whole soil & $10.6(0.9)$ & \multicolumn{11}{|c|}{ 440-d incubation } \\
\hline LF & $0.3(0.02)$ & 2.9 & $0.4(0.02)$ & 2.3 & $0.3(0.02)$ & 3.3 & $0.3(0.03)$ & 2.3 & $0.5(0.02)$ & 2.0 & $0.3(0.02)$ & 2.8 \\
\hline POM + sand & $2.3(0.1)$ & 23.9 & $2.3(0.7)$ & 12.9 & $2.3(0.3)$ & 24.1 & $3.3(0.1)$ & 23.9 & $2.4(0.1)$ & 10.3 & $2.0(0.3)$ & 20.5 \\
\hline Silt & $2.5(0.2)$ & 26.2 & $4.3(0.8)$ & 24.4 & $1.4(0.3)$ & 15.1 & $3.4(0.4)$ & 25.0 & $5.0(0.7)$ & 22.1 & $1.7(0.4)$ & 18.1 \\
\hline Clay & $3.5(0.3)$ & 37.2 & $8.6(2.0)$ & 49.4 & $5.2(0.1)$ & 54.1 & $5.2(0.7)$ & 38.3 & $14.6(2.2)$ & 64.3 & $5.5(0.4)$ & 57.8 \\
\hline Soluble C & $0.8 \S$ & 9.7 & $1.8 \S$ & 11.0 & $0.3 \S$ & 3.3 & $1.3 \S$ & 10.5 & $0.4 \S$ & 1.4 & $0.5 \S$ & 0.9 \\
\hline Whole soil & \multicolumn{12}{|c|}{ 800-d incubation } \\
\hline LF & $0.2(0.03)$ & 2.1 & $0.2(0.01)$ & 1.0 & $0.2(0.02)$ & 2.9 & $0.2(0.05)$ & 1.8 & $0.3(0.02)$ & 1.2 & $0.2(0.01)$ & 2.0 \\
\hline POM + sand & $2.0(0.1)$ & 22.1 & $2.3(0.1)$ & 13.8 & $2.2(0.2)$ & 25.0 & $3.3(0.3)$ & 25.7 & $2.3(0.1)$ & 11.4 & $1.8(0.1)$ & 19.5 \\
\hline Silt & $2.6(0.8)$ & 29.0 & $4.3(0.2)$ & 25.8 & $1.6(0.3)$ & 18.4 & $3.8(0.7)$ & 29.9 & $5.2(0.8)$ & 25.5 & $1.9(0.6)$ & 21.1 \\
\hline Clay & $3.4(0.7)$ & 38.1 & $8.4(1.4)$ & 50.8 & $4.2(0.6)$ & 47.4 & $4.3(0.9)$ & 33.6 & $10.8(1.1)$ & 52.8 & $4.4(0.8)$ & 48.0 \\
\hline Soluble C & $0.8 \S$ & 8.8 & $1.4 \S$ & 8.7 & $0.6 \S$ & 6.3 & $1.1 \S$ & 9.0 & $1.9 \S$ & 9.2 & $0.9 \S$ & 9.4 \\
\hline Whole soil & $9.0(0.3)$ & & $16.6(0.2)$ & & $8.8(0.6)$ & & $12.6(0.5)$ & & $20.4(0.3)$ & & $9.1(0.6)$ & \\
\hline
\end{tabular}

+ Values in parentheses are standard errors of the mean at $P=0.05$.

₹ Soluble $\mathrm{C}$ defined as the $\mathrm{C}$ unaccounted for following the fractionation process.

$\S$ Estimated by subtraction. 
Table 3. Organic $C$ distribution, $\delta^{13} \mathrm{C}$, and $\mathrm{C}$ derived from $\mathrm{C}_{4}$ residue inputs among light fraction (LF), particulate organic matter (POM), silt, and clay soil fractions, soluble $C$, and the whole soil during long-term incubation of the Lamberton, $M N$, soil. Native soil $\delta^{13} \mathrm{C}=-19.3(0.4) \%$.

\begin{tabular}{|c|c|c|c|c|c|c|c|c|}
\hline \multirow{3}{*}{ Soil fraction } & \multicolumn{4}{|c|}{ Unfertilized } & \multicolumn{4}{|c|}{ Fertilized (160 $\left.\mathrm{kg} \mathrm{N} \mathrm{ha}^{-1}\right)$} \\
\hline & \multicolumn{2}{|c|}{ C distribution } & \multirow{2}{*}{$\delta{ }^{13} \mathrm{C}$} & \multirow{2}{*}{$\begin{array}{c}C \text { derived from } \\
\mathrm{C}_{4} \text { inputs }\end{array}$} & \multicolumn{2}{|c|}{ C distribution } & \multirow{2}{*}{$\delta^{13} \mathrm{C}$} & \multirow{2}{*}{$\begin{array}{c}C \text { derived } \\
\text { from } C_{4} \text { input }\end{array}$} \\
\hline & Content & Proportion & & & Content & Proportion & & \\
\hline & $\mathrm{g} \mathrm{C} \mathrm{kg}^{-1}$ & $\%$ & $\%$ & $\%$ & $\mathrm{~g} \mathrm{C} \mathrm{kg}^{-1}$ & $\%$ & $\%$ & $\%$ \\
\hline & \multicolumn{8}{|c|}{ Initial } \\
\hline LF & $0.5(0.1)+$ & 2.5 & $-12.9(0.2)$ & $87.7(3.1)$ & $0.7(0.1)$ & 3.5 & $-12.7(0.4)$ & $90.3(7.9)$ \\
\hline POM + sand & $1.1(0.1)$ & 5.3 & $-15.1(0.4)$ & $59.1(1.3)$ & $1.2(0.1)$ & 5.8 & $-14.6(0.2)$ & $65.9(3.7)$ \\
\hline Silt & $3.4(0.3)$ & 16.5 & $-16.4(0.2)$ & $41.9(1.3)$ & $3.1(0.4)$ & 15.1 & $-15.8(0.2)$ & $49.2(4.4)$ \\
\hline Clay & $13.5(1.0)$ & 66.1 & $-16.7(0.2)$ & $37.4(2.0)$ & $13.9(1.2)$ & 68.4 & $-16.3(0.2)$ & $42.6(2.2)$ \\
\hline Soluble C $\neq$ & $1.9 \S$ & 9.6 & & & $1.5 \S$ & 7.2 & & \\
\hline \multirow[t]{2}{*}{ Whole soil } & $20.4(0.4)$ & & $-16.4(0.1)$ & $39.3(0.9)$ & $20.4(0.5)$ & & $-16.4(0.3)$ & $41.5(5.5)$ \\
\hline & \multicolumn{8}{|c|}{ 440-d incubation } \\
\hline LF & $0.2(0.02)$ & 1.1 & $-14.6(0.5)$ & $64.5(6 . \overline{5})$ & $0.3(0.1)$ & 1.4 & $-14.2(0.3)$ & $69.7(4.0)$ \\
\hline POM + sand & $1.4(0.1)$ & 7.4 & $-16.8(0.2)$ & $34.7(3.3)$ & $1.5(0.1)$ & 8.3 & $-16.6(0.3)$ & $37.0(3.5)$ \\
\hline Silt & $3.3(0.2)$ & 17.8 & $-18.3(0.5)$ & $13.3(1.5)$ & $3.2(0.5)$ & 17.8 & $-17.7(0.2)$ & $22.2(1.5)$ \\
\hline Clay & $12.4(1.5)$ & 66.1 & $-16.7(0.6)$ & $35.6(0.6)$ & $12.6(1.4)$ & 66.8 & $-16.6(0.2)$ & $36.9(2.8)$ \\
\hline Soluble C & $1.4 \S$ & 7.7 & & & $0.4 \S$ & 2.7 & & \\
\hline \multirow[t]{2}{*}{ Whole soil } & $18.7(0.6)$ & & $-16.9(0.2)$ & $32.8(2.4)$ & $18.0(0.4)$ & & $-16.6(0.3)$ & $37.1(4.4)$ \\
\hline & \multicolumn{8}{|c|}{ 800-d incubation } \\
\hline LF & $0.2(0.01)$ & 0.8 & $-15.6(0.6)$ & $51.4(5.2)$ & $0.2(0.08)$ & 0.8 & $-16.3(0.4)$ & $40.6(4.9)$ \\
\hline $\mathrm{POM}+$ sand & $1.3(0.2)$ & 7.7 & $-17.6(0.4)$ & $24.0(3.6)$ & $1.6(0.05)$ & 9.3 & $-17.9(0.2)$ & $22.2(3.0)$ \\
\hline Silt & $3.4(0.2)$ & 19.8 & $-18.8(0.2)$ & $7.6(1.4)$ & $3.5(0.2)$ & 19.8 & $-18.4(0.1)$ & $12.2(1.4)$ \\
\hline Clay & $10.8(1.2)$ & 62.3 & $-17.9(0.2)$ & $19.7(1.2)$ & $10.8(0.6)$ & 61.2 & $-17.7(0.4)$ & $22.1(5.1)$ \\
\hline Soluble C & $1.7 \S$ & 9.4 & & & $1.5 \S$ & 9.0 & & \\
\hline Whole soil & $17.4(0.4)$ & & $-17.0(0.1)$ & $31.6(2.1)$ & $17.6(0.1)$ & & $-16.8(0.5)$ & $34.3(4.6)$ \\
\hline
\end{tabular}

+ Values in parentheses are standard errors of the mean at $P=0.05$.

\# Soluble $\mathrm{C}$ defined as the $\mathrm{C}$ unaccounted for following the fractionation process.

$\S$ Estimated by subtraction.

that floatable organic $\mathrm{C}$ (which is comparable to the POM fraction of our study) accounted for 8 to $14 \%$ of the SOC in cultivated soil. The POM fraction accounted for 5 to $11 \%$ of the SOC in the fine-textured ( $>31 \%$ clay) soils at Lamberton, MN (Table 3), and Hoytville, OH (Table 2), compared with a range of 17 to $23 \%$ of the SOC in the KBS, MI, and Wooster, $\mathrm{OH}$, soils that contained $<20 \%$ clay (Table 2 ). There was no significant difference in the concentrations of LF and the POM fractions between the two tillage treatments. The highest proportion of the SOC content was found in the clay-size fraction ranging from $36 \%\left(3.8 \mathrm{~g} \mathrm{C} \mathrm{kg}^{-1}\right)$ of the SOC in the CT treatment of the Wooster soil (Table 2) to $68.4 \%\left(13.9 \mathrm{~g} \mathrm{C} \mathrm{kg}^{-1}\right)$ in the fertilized Lamberton soil (Table 3). The NT treatments among all sites showed a higher $\mathrm{C}$ enrichment in the clay fraction than in CT. In contrast, silt fractions were more enriched in C in the CT than NT soils before incubation. Silt-associated organic C accounted for 16 to $28 \%$ of the SOC.

The proportion of $\mathrm{C}$ contained in the LF decreased an average of $65 \%$ among all treatments in the samples incubated for $800 \mathrm{~d}$. The majority of the loss in LF-C occurred during the first $400 \mathrm{~d}$ of incubation. There was no significant difference in the loss of LF-C among CT and NT treatments for any of the incubated soils (Table 2). The loss of C from LF was attributed to mineralization of the labile fractions that contain partly decomposed plant residues, as well as the turnover of microbial biomass (Anderson et al., 1981; Tiessen and Stewart, 1983; Janzen et al., 1992; Gregorich et al., 1995). The C concentration and distribution (percentage of SOC) in the POM, silt-associated, and clay fractions did not change significantly during $800 \mathrm{~d}$ of incubation. The decomposition of the LF might have contributed to a transfer of $\mathrm{C}$ to the POM and silt fractions, as suggested by Tiessen and Stewart (1983). The fractionation procedure used in this study resulted in losses of soluble organic $\mathrm{C}$ and some of the mineral fractions, with a maximum estimated loss of $10 \%$.

\section{The Carbon and Nitrogen Composition of the Fractions}

The LF and POM, being closely related to plant residues and associated microbial decomposition products, had the expected wide $\mathrm{C} / \mathrm{N}$ ratios (Greenland and Ford,1964; Dalal and Mayer, 1986a; Christensen, 1992). It decreased from $\sim 21$ in the LF to around 8 in the clay fraction of Hoytville (Table 4). The $\mathrm{C} / \mathrm{N}$ ratio of the POM fraction ( 14.5) was intermediate between the LF and heavy fractions. That of the silt was similar to the whole soil. The clay fraction had the narrowest $\mathrm{C} / \mathrm{N}$ ratio (6.3-10.2). Christensen and Sorensen (1985) incubated soils for $5 \mathrm{yr}$ with ${ }^{15} \mathrm{~N}-\mathrm{NH}_{4}$ and ${ }^{14} \mathrm{C}$-hemicellulose and found that the $\mathrm{C} / \mathrm{N}$ ratio of labeled, organic $\mathrm{C}$ associated with clay was lower and that associated with silt was higher than that of the whole soils. The Hoytville soil had the highest clay content (50\%) and this clay had the narrowest $\mathrm{C} / \mathrm{N}$ ratio (6.3-6.7).

There are two possible explanations for the narrow $\mathrm{C} / \mathrm{N}$ ratio of the clay. Fixed $\mathrm{NH}_{4}$, the $\mathrm{NH}_{4}^{+}$ion fixed within the lattice of clay minerals, has been found to occur in clays of the U.S. Midwest. Others (Smith and Young, 1975; Stevenson and Dhariwal, 1959) have reported that clays similar to those in the soils of this study had a fixed $\mathrm{NH}_{4}$ content of $2 \mathrm{cmol} \mathrm{kg}^{-1}$ clay. Correcting the $\mathrm{C} / \mathrm{N}$ ratios of the clay for fixed $\mathrm{NH}_{4}$ would result in ratios of C/organic $\mathrm{N}$ of 9.5 for the clay from Wooster, 7.4 for Hoytville, 9.3 for KBS, and 10.1 for Lamberton. The corrected values are similar to the $\mathrm{C} / \mathrm{N}$ ratios of the total soil $\mathrm{C}$. 
Table 4. Carbon/nitrogen ratio of light fraction (LF), particulate organic matter (POM), silt, and clay soil fractions and the whole soil initially and after $\mathbf{4 4 0}$ or $\mathbf{8 0 0} \mathrm{d}$ of laboratory incubation.

\begin{tabular}{|c|c|c|c|c|c|c|}
\hline \multirow{3}{*}{ Soil fraction } & \multicolumn{6}{|c|}{$\mathrm{C} / \mathrm{N}$ ratio } \\
\hline & \multicolumn{3}{|c|}{ Conventional tillage } & \multicolumn{3}{|c|}{ No-till } \\
\hline & Initial & $440 \mathrm{~d}$ & $800 \mathrm{~d}$ & Initial & $440 \mathrm{~d}$ & $800 \mathrm{~d}$ \\
\hline \multicolumn{7}{|l|}{ Wooster, $\mathrm{OH}$} \\
\hline LF & $22.2 \mathrm{at}$ & $21.8 \mathrm{a}$ & $21.9 \mathrm{a}$ & $20.9 \mathrm{a}$ & $20.4 \mathrm{a}$ & $20.1 \mathrm{a}$ \\
\hline $\mathrm{POM}+$ sand & $14.4 \mathrm{~b}$ & $14.3 \mathrm{~b}$ & $14.2 \mathrm{~b}$ & $15.7 \mathrm{~b}$ & $14.8 \mathrm{~b}$ & $14.5 \mathrm{~b}$ \\
\hline Silt & $10.1 \mathrm{C}$ & $8.5 \mathrm{~d}$ & $8.1 \mathrm{~d}$ & $10.3 \mathrm{C}$ & $9.6 \mathrm{C}$ & $9.1 \mathrm{~cd}$ \\
\hline Clay & $8.2 \mathrm{~d}$ & $7.8 \mathrm{~d}$ & $7.6 \mathrm{~d}$ & $8.2 \mathrm{~d}$ & $7.5 \mathrm{~d}$ & $7.4 \mathrm{~d}$ \\
\hline Whole soil & $10.0 \mathrm{c}$ & $9.3 \mathrm{c}$ & $8.5 \mathrm{~d}$ & $11.2 \mathrm{e}$ & $10.4 \mathrm{c}$ & $8.2 \mathrm{~d}$ \\
\hline \multicolumn{7}{|l|}{ Hoytville, $\mathrm{OH}$} \\
\hline LF & $19.6 \mathrm{C}$ & $19.5 \mathrm{C}$ & $19.4 \mathrm{C}$ & $19.4 \mathrm{~b}$ & $19.3 \mathrm{~b}$ & $19.2 \mathrm{c}$ \\
\hline POM + sand & $15.0 \mathrm{de}$ & $14.6 \mathrm{de}$ & $14.4 \mathrm{~d}$ & $14.9 \mathrm{~d}$ & $14.3 \mathrm{de}$ & 14.2 ef \\
\hline Silt & $10.3 \mathrm{~g}$ & $9.3 \mathrm{~h}$ & $9.0 \mathrm{fg}$ & $10.1 \mathrm{f}$ & $9.8 \mathrm{hi}$ & $9.5 \mathrm{gh}$ \\
\hline Clay & $6.5 \mathrm{j}$ & 6.41 & $6.3 \mathrm{k}$ & $6.7 \mathrm{~h}$ & $6.4 \mathrm{k}$ & $6.4 I^{\circ}$ \\
\hline Whole soil & $9.8 \mathrm{gh}$ & $9.0 \mathrm{hi}$ & $8.0 \mathrm{ij}$ & $10.2 \mathrm{f}$ & $9.4 \mathrm{hi}$ & $8.2 \mathrm{j}$ \\
\hline \multicolumn{7}{|l|}{ Kellogg Biological Stn., MI } \\
\hline LF & $21.0 \mathrm{~b}$ & $20.1 \mathrm{bc}$ & $20.4 \mathrm{~b}$ & $21.2 \mathrm{a}$ & $20.6 \mathrm{a}$ & $20.6 \mathrm{a}$ \\
\hline $\mathrm{POM}+$ sand & $15.2 \mathrm{~d}$ & $15.0 \mathrm{~d}$ & $14.0 \mathrm{~d}$ & $15.2 \mathrm{~cd}$ & $14.99 \mathrm{C}$ & 14.5 ef \\
\hline Silt & $10.0 \mathrm{gh}$ & $9.4 \mathrm{gh}$ & $8.8 \mathrm{gh}$ & 10.5 ef & $9.6 \mathrm{hi}$ & $8.9 \mathrm{i}$ \\
\hline Clay & $8.5 \mathrm{i}$ & $7.8 \mathrm{jk}$ & $7.7 j^{\circ}$ & $7.8 \mathrm{~g}$ & $7.8 \mathrm{j}$ & $7.8 \mathrm{k}$ \\
\hline Whole soil & $10.4 \mathrm{~g}$ & $10.7 \mathrm{f}$ & $8.8 \mathrm{fgh}$ & $10.3 \mathrm{f}$ & $9.8 \mathrm{gh}$ & $9.0 \mathrm{i}$ \\
\hline & & $\underline{\text { Unfertilized }}$ & & & $160 \mathrm{~N} \mathrm{~kg} \mathrm{ha}^{-1}$ & \\
\hline \multicolumn{7}{|l|}{ Lamberton, MN } \\
\hline LF & $21.0 \mathrm{~b}$ & $20.6 \mathrm{~b}$ & $20.5 \mathrm{~b}$ & $20.7 \mathrm{a}$ & $20.3 \mathrm{a}$ & $16.7 \mathrm{~d}$ \\
\hline POM + sand & $14.9 \mathrm{de}$ & $14.5 \mathrm{de}$ & $14.1 \mathrm{~d}$ & $14.7 \mathrm{~d}$ & $14.2 \mathrm{e}$ & $14.1 \mathrm{f}$ \\
\hline Silt & $11.4 \mathrm{f}$ & $10.4 \mathrm{f}$ & $10.3 \mathrm{e}$ & 10.5 ef & $10.4 \mathrm{f}$ & $9.7 \mathrm{~g}$ \\
\hline Clay & $9.4 \mathrm{~h}$ & $9.3 \mathrm{~h}$ & $9.2 \mathrm{fg}$ & $10.2 \mathrm{f}$ & $9.3 \mathrm{i}$ & $9.3 \mathrm{hi}$ \\
\hline Whole soil & $10.4 \mathrm{~g}$ & $10.0 \mathrm{fg}$ & $9.5 \mathrm{f}^{\circ}$ & $11.0 \mathrm{e}$ & $10.3 \mathrm{fg}$ & $9.5 \mathrm{gh}$ \\
\hline
\end{tabular}

${ }^{\dagger}$ Comparisons were made within a site, among fractions, and between treatments. Means with the same letter are not significantly different at $p=0.05$ level.

The $\mathrm{C}$ content of the clay ranged from $20 \mathrm{~g} \mathrm{C} \mathrm{kg}^{-1}$ clay in the Wooster and Hoytville soils to $28 \mathrm{~g} \mathrm{C} \mathrm{kg}^{-1}$ clay in $\mathrm{KBS}$ and $43 \mathrm{C} \mathrm{kg}^{-1}$ clay in the Lamberton soil. Buyanovsky et al. (1994) suggested that the $C$ associated with the clay fraction may be highly processed and stable compared with organic matter (OM) associated with silt and sand fractions. Anderson and Paul (1984) found the relative ${ }^{14} \mathrm{C}$ content of silt, coarse clay, and fine clay to depend on soil type. In some soils, coarse clay had higher MRTs than silt. In all cases, the fine clays had low MRTs and many showed the influence of recent bomb C. Sorensen (1972) showed the preferential absorption of amino acids to clay, and recent literature (Sollins et al., 2006) has suggested that clays build up amino-rich compounds in an onionlike structure of amino acids layered onto the clay. This could, in part, cause the narrow $\mathrm{C} / \mathrm{N}$ ratios. The correction for fixed $\mathrm{NH}_{4}$ changes the $\mathrm{C} / \mathrm{N}$ ratio of the clay to nearly that of the silts, suggesting that this may be the more important mechanism of the two.

\section{Carbon-13 Values of Soil Organic Carbon Fractions before and after Incubation}

On average, across all sites, $\delta^{13} \mathrm{C}$ values of the native soils differed by $3 \%$ from the adjacent cultivated whole soil, enabling us to identify changes in the composition of $\mathrm{C}_{3}$ (forest and prairie) and $\mathrm{C}_{4}$ (corn) $\mathrm{C}$ with time of incubation and calculate the mean residence time of $\mathrm{C}$ within different organic fractions in the whole soil. The $\delta^{13} \mathrm{C}$ values of the LF ranged from $-12.7 \%$ at Lamberton, MN (Table 3), to $-18.2 \%$ at KBS, MI, before incubation (Table 5). The more negative $\delta^{13} \mathrm{C}$ value for the KBS LF was probably due to the shorter period $(\sim 8 \mathrm{yr})$ this site was under continuous corn compared with $>30 \mathrm{yr}$ for the other three sites. The $\delta^{13} \mathrm{C}$ values for the LF of the Wooster, Hoytville (Table 5), and Lamberton (Table 3) sites were -14.9, -14.1, and $-12.7 \%$, respectively, indicating that it consists mainly of corn $\left(\mathrm{C}_{4}-\mathrm{C}\right)$ derived residues. The $\delta^{13} \mathrm{C}$ values of the POM, silt, and clay fractions of all sites show a consistent decline in enrichment of $\mathrm{C}_{4}-\mathrm{C}$. The $\delta^{13} \mathrm{C}$ contents of the whole soils were similar to the values of the silt fractions among all sites. Collins et al. (2000) reported that the $\delta^{13} \mathrm{C}$ values of the native soils were $-26.1 \%$ at KBS, $-25.5 \%$ at Wooster, $-24.8 \%$ at Hoytville, and $-19.5 \%$ at Lamberton.

After $800 \mathrm{~d}$ of incubation, ${ }^{13} \mathrm{C}$ values of the LF became less enriched in $\mathrm{C}_{4}-\mathrm{C}$ than that of the POM, silt, and clay organic fractions. The $\delta^{13} \mathrm{C}$ of the LF decreased $6 \%$ in the Wooster soil and 3 to $5 \%$ at the other sites (Table 5). Although initial ${ }^{13} \mathrm{C}$ values of the LF for the Wooster and Hoytville soils (Table 5) were similar, the greater decrease in Wooster $(6 \%$ ) than Hoytville (4\%o) soils reflects a higher turnover rate of $\mathrm{C}_{4}-\mathrm{C}$ at Wooster (Table 6). The rate of turnover decreased in the order Wooster $>$ Hoytville $>$ KBS $>$ Lamberton based on changes in the $\delta^{13} \mathrm{C}$ values of the LF with incubation. As with the LF, the POM in the Wooster and Hoytville soils had greater depletion $(\sim 4.5 \%)$ than the KBS or Lamberton $(\sim 2.5 \%$ o $)$ soils. Since POM is commonly associated with aggregates, it is better protected from decomposition than the LF, resulting in less depletion. The silt and clay fractions showed less depletion, ranging from $2.6 \%$ o to almost no change with incubation. The silt-size organic fraction was most depleted at Lamberton $(2.6 \%$ ) and the least depletion was observed at Hoytville $(0.8 \%$ o). The clay-size organic fraction depletion ranged from $1.91 \%$ at Wooster to $0.46 \%$ at KBS. The clay-size organic 
fraction of the Hoytville soils showed an average of $0.1 \%$ enrichment with $800 \mathrm{~d}$ of incubation.

The type of tillage was not a factor in affecting the loss of $\mathrm{C}_{4}-\mathrm{C}$ during incubation. Light fraction and POM had turnover times averaging 4 and $9 \mathrm{yr}$, respectively, on a field-equivalent basis. The POM fraction after $800 \mathrm{~d}$ of incubation had ${ }^{13} \mathrm{C}$ values similar to that of the whole soil. The silt fraction was more depleted than the clay fraction after $440 \mathrm{~d}$ of incubation in the coarser textured sites (KBS and Lamberton). During the incubations of these soils, Collins et al. (2000) showed that $>50 \%$ of the $\mathrm{CO}_{2}$ evolved during the first $100 \mathrm{~d}$ was derived from corn residue and, even after $>800 \mathrm{~d}$ of incubation, the $\delta^{13} \mathrm{C}$ of the $\mathrm{CO}_{2}$ from the Hoytville soil was enriched by $2 \%$.

\section{Corn-Derived Carbon and Turnover Time}

After $\sim 30 \mathrm{yr}$ of cropping, the proportion of $\mathrm{C}$ derived from corn was 22,38 , and $42 \%$ in the whole soil for the Wooster, Hoytville (Table 5), and Lamberton (Table 3) sites, respectively. The KBS site, with a shorter period of continuous corn cropping, showed the least incorporation of corn residue ( $21 \%$ for CT and $22 \%$ for NT) into the SOM (Table 5). Hoytville, although cropped for $30 \mathrm{yr}$, showed a similar low incorporation of $\mathrm{C}_{4}-\mathrm{C}$ in the whole soil (Table 5). This may have resulted from the high clay content and poorly drained characteristics of this site. Our findings are similar to the 25 to $35 \%$ estimate of Gregorich et al. (1997) after 25 yr and the 34\% estimate by Balesdent et al. (1988) after $36 \mathrm{yr}$ of continuous corn cropping. The proportion of corn-derived $\mathrm{C}$ in the LF ranged from 56 to $84 \%$ under CT and 60 to $85 \%$ in the NT treatments. The LF, which is relatively undecomposed and has a $\mathrm{C} / \mathrm{N}$ ratio of $\sim 21$ (Table 4), is biologically very active. Except for the KBS site, $<20 \%$ of the $\mathrm{C}_{3}$-derived organic $\mathrm{C}$ has remained in the LF. The KBS site has been continuously cropped to corn for $8 \mathrm{yr}$, before which the rotation was a cornsoybean-wheat (Triticum aestivum L.) rotation.

In the POM fraction, corn-derived $\mathrm{C}$ ranged from 38 to $64 \%$ under CT and 46 to $70 \%$ in NT soils (Table 5). As Goldchin et al. (1995) and Gregorich et al. (1997) pointed out, aggregation is a continuous process and thus the composition of the organic pool depends on the cropping history. They suggested that the physically protected $\mathrm{LF}$, and in this case the POM, is a relatively older stabilized pool of $\mathrm{C}$ compared with the unprotected LF. In both fractions, slightly more cornderived $\mathrm{C}$ is found under NT than CT due to slower decomposition of residue at the surface of the NT treatments. Soil C derived from corn residue in the silt averaged $19,20,36$, and $46 \%$, and $23,11,30$, and $40 \%$ in the clay size fractions,

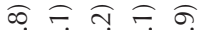

$\stackrel{\ominus}{\ominus} \varrho$

華

$\stackrel{\circ}{\ominus} \dot{0}=$

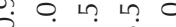

ᄃ

o 0 증

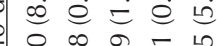

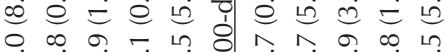

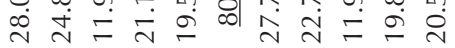

$\widehat{\bar{n}} \overline{\mathrm{m}} \tilde{\mathrm{\sigma}}$

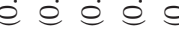

4.

तิ

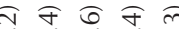

$=\widehat{\infty} \bar{\sigma} \bar{m}$

लें $\dot{0} \dot{0}=0$

on 0 . nt

ळ

m $\bar{n}=\tilde{=}$

$\stackrel{2}{\varrho} \ddot{0} \dot{0} \check{0}$

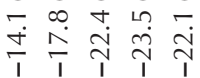

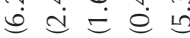

t. ᄂ?

官 ம்

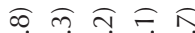

$\dot{\theta} \varrho \dot{e} \dot{\theta}$

$\stackrel{n}{n} \stackrel{n}{0} \stackrel{\infty}{i} \stackrel{m}{n} \stackrel{n}{\sim}$

Tิণ

$\hat{\bar{x}} \widehat{\mathrm{x}} \widehat{\mathrm{x}} \overline{\mathrm{m}}$

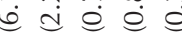
ด. $\wedge$. फ

o $\bar{m} \hat{m}=$ $\dot{e} \stackrel{\dot{e}}{\varrho} \dot{e}$ ง ๙

oิ $\overline{\mathrm{n}} \overline{\mathrm{m}}$ $\infty \bar{\infty} \overline{\mathrm{m}} \overline{\mathrm{c}}$ $=0 \mathrm{~d}=0$

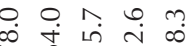

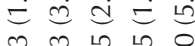

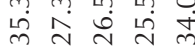

ถิก $\bar{\sigma} \sigma \widehat{m}$ ம0.

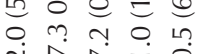
लं ते ৯े

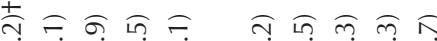

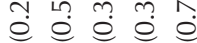

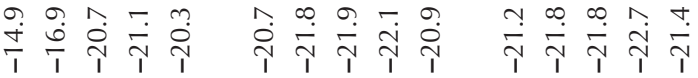

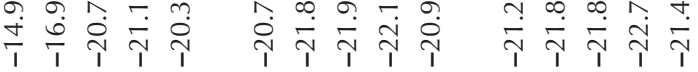

$\hat{\kappa}=\hat{=} \bar{a}$

$\dot{\theta} \dot{e} \dot{\ominus} \dot{0}$

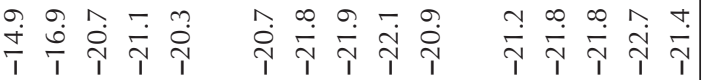

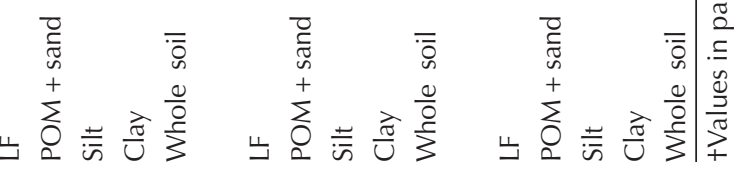


Table 6. Mean residence time (MRT) of $\mathrm{C}_{4}-\mathrm{C}$ for the light fraction (LF), particulate organic matter (POM), silt, and clay fractions of cultivated soils under conventional tillage (CT) and no-till (NT).

\begin{tabular}{|c|c|c|c|c|c|c|c|c|}
\hline \multirow{2}{*}{ Site and treatment } & \multicolumn{2}{|c|}{ Light fraction } & \multicolumn{2}{|c|}{ Particulate organic matter } & \multicolumn{2}{|c|}{ Silt } & \multicolumn{2}{|c|}{ Clay } \\
\hline & Lab MRT & Field MRT† & Lab MRT & Field MRT & Lab MRT & Field MRT & Lab MRT & Field MRT \\
\hline & $d$ & $\mathrm{yr}$ & $d$ & $\mathrm{yr}$ & $d$ & $\mathrm{yr}$ & $d$ & $\mathrm{yr}$ \\
\hline \multicolumn{9}{|l|}{ Wooster, $\mathrm{OH}$} \\
\hline $\mathrm{CT}$ & $321(33) \ddagger$ & $2.6(0.3)$ & $676(110)$ & $5.6(0.9)$ & $1927(199)$ & $15.9(1.6)$ & $1451(138)$ & $12.0(1.1)$ \\
\hline NT & 386 (29) & $3.2(0.2)$ & 800 (159) & $6.6(1.3)$ & $2524(180)$ & $20.8(1.5)$ & $860(92)$ & $7.1(0.5)$ \\
\hline \multicolumn{9}{|l|}{ Hoytville, $\mathrm{OH}$} \\
\hline $\mathrm{CT}$ & $459(36)$ & $3.7(0.3)$ & $971(91)$ & $7.8(0.7)$ & $1597(26)$ & $12.8(0.5)$ & $3342(153)$ & $26.8(1.2)$ \\
\hline NT & $495(6)$ & $4.0(1.0)$ & $1068(32)$ & $8.6(0.3)$ & $1034(34)$ & $8.3(0.3)$ & $2003(16)$ & $16.1(0.2)$ \\
\hline \multicolumn{9}{|c|}{ Kellogg Biological Stn., MI } \\
\hline $\mathrm{CT}$ & $467(69)$ & $3.9(0.6)$ & $1368(136)$ & $11.4(1.1)$ & $1314(75)$ & $10.9(1.0)$ & $1985(150)$ & $16.5(0.5)$ \\
\hline NT & $459(12)$ & $3.8(0.1)$ & $1377(134)$ & $11.4(1.1)$ & $1174(130)$ & $9.7(1.1)$ & $1078(98)$ & $9.0(1.0)$ \\
\hline \multicolumn{9}{|l|}{ Lamberton, MN } \\
\hline $0 \mathrm{~N}$ & $379(27)$ & $3.8(0.3)$ & 1267 (118) & $12.8(1.2)$ & $469(20)$ & $4.7(1.0)$ & $910(17)$ & $9.2(0.2)$ \\
\hline $160 \mathrm{~kg} \mathrm{~N}$ & $337(11)$ & $3.4(0.1)$ & $1111(74)$ & $11.2(0.8)$ & $628(10)$ & $6.3(0.4)$ & $881(51)$ & $8.9(0.5)$ \\
\hline
\end{tabular}

+Mean residence times converted to field rates using a $\mathrm{Q}_{10}$ of $2\left[2^{(25-\mathrm{t}) / 10}\right]$, where $t=$ mean annual temperature.

‡Standard error of the mean in parentheses.

for the KBS, Hoytville, Wooster (Table 5), and Lamberton sites (Table 3), respectively.

The silt- and clay-size organic fractions had much less corn-derived C than LF or POM, suggesting that finer size particles with greater surface area provide physical protection of the older $\mathrm{C}_{3}-\mathrm{C}$. Higher concentrations of organic $\mathrm{C}$ (50-70\% of total soil C) and relatively more stable organic C was found in the clay-size fractions as indicated by the isotopic composition. Thus, after $>30 \mathrm{yr}$ of corn cropping, the silt- and clay-size organic fractions are dominated by older $\mathrm{C}_{3}-\mathrm{C}$ (Table 7). The silt- and clay-size organic $\mathrm{C}$ is more stable than the $\mathrm{LF}$ and POM and contributes to long-term soil fertility. Clay and OM content appear to have a greater correlation in most soils due to physical protection of the OM by mineral particles and resistance to biochemical reaction in the soil.

The change in the percentage of SOC derived from corn and incorporated into LF, POM, silt, clay, and whole soils after 440 and $800 \mathrm{~d}$ of laboratory incubation is shown in Tables 3 and 5. The greatest loss of $\mathrm{C}_{4}$-derived $\mathrm{C}$ was observed for the LF (31-59\%) and POM (40-66\%) fractions. After $800 \mathrm{~d}$ of

Table 7. Field mean residence times (MRT) + of $\mathrm{C}_{3}-\mathrm{C}$ for the light fraction (LF), particulate organic matter (POM), silt, and clay fractions of cultivated soils under conventional tillage (CT) and no-till (NT). Assumes $C$ at time of study initiation was all $\mathrm{C}_{3}-\mathrm{C}$ and that the concentration of $\mathrm{C}_{3}-\mathrm{C}$ did not increase due to cropping of continuous corn.

\begin{tabular}{lcccc}
\multicolumn{1}{c}{ Site and treatment } & $\begin{array}{c}\text { LF } \\
\text { MRT }\end{array}$ & $\begin{array}{c}\text { POM } \\
\text { MRT }\end{array}$ & $\begin{array}{c}\text { Silt } \\
\text { MRT }\end{array}$ & $\begin{array}{c}\text { Clay } \\
\text { MRT }\end{array}$ \\
\cline { 2 - 5 } & & & & \\
Wooster, OH & & & \\
$\quad$ CT & 20.5 & 30.3 & 70.2 & 78.6 \\
$\quad$ NT & 16.7 & 27.7 & 68.5 & 90.5 \\
Hoytville, OH & & & & \\
$\quad$ CT & 17.2 & 38.1 & 139 & 261.0 \\
$\quad$ NT & 16.4 & 33.7 & 140 & 273.9 \\
Kellogg Biological Stn., MI & & & & \\
$\quad$ CT & 19.7 & 33.4 & 47.1 & 40.0 \\
$\quad$ NT & 17.0 & 26.0 & 43.5 & 31.8 \\
$\quad$ Lamberton, MN & & & & \\
$\quad$ O N & 15.8 & 36.9 & 60.8 & 70.5 \\
$\quad$ 160 kg N & 14.1 & 30.7 & 48.7 & 59.5 \\
\hline
\end{tabular}

+ Mean residence times converted to field rates using a $Q^{10}$ of 2 $\left[2^{(25-\mathrm{t}) / 10}\right]$, where $t=$ mean annual temperature. incubation, almost half of the original $\mathrm{C}_{4}$-derived $\mathrm{C}$ had been mineralized, which suggests that these fractions are responsible for the short- and medium-term fertility of the soil.

The clay-sized $\mathrm{C}$ fraction showed the least loss of $\mathrm{C}_{4}$-derived $\mathrm{C}$, followed by the silt-size fraction. The loss of clay-size $\mathrm{C}_{4}-$ derived $\mathrm{C}$ was greater than the silt-size fraction in Wooster soils. This supports previous studies (Martel and Paul, 1974; Dalal and Mayer, 1986a, 1986b) that the clay-fraction OM is more labile than the silt-associated organic $C$. In all the other sites, the silt-size organic $\mathrm{C}$ fraction showed relatively faster turnover of corn-derived organic $\mathrm{C}$ and this observation (silt-associated $\mathrm{OM}$ is more labile than clay) is not common in temperate soils (Christensen, 1987). Balesdent et al. (1987) observed that the organic $C$ associated with the clay fraction was very heterogeneous with regard to degradability. Anderson and Paul (1984) found the SOC of coarse clays to have a high MRT while the fine clays were much younger. This study did not fractionate the clay into two sizes.

The mean residence time $(\mathrm{MRT}=1 / k)$ of corn-derived C in the LF and POM fractions was estimated by assuming an exponential decay of the original organic $\mathrm{C}\left(C_{\mathrm{o}}\right)$ in each fraction with 440 and $800 \mathrm{~d}$ of incubation (Table 6). The estimated average MRT of corn-derived $\mathrm{C}$ in the LF across sites was 3.5 and $9.4 \mathrm{yr}$ for the POM fraction. The POM fraction of the Wooster and Hoytville soils had a lower MRT (5.6-8.6 yr) than that of the KBS and Lamberton soils, which averaged $\sim 12 \mathrm{yr}$. This result was expected in the field situation where the mean annual temperature in Ohio is higher than at KBS or Lamberton, indicating a faster turnover. With laboratory incubations, however, soils from cold sites (KBS and Lamberton) would be expected to turn over faster because of a greater concentration of labile $\mathrm{OM}$ than in the warmer soils of Ohio. Other factors such as the extent of aggregation could have played a role, but fractionation into aggregates sizes and determination of their ${ }^{13} \mathrm{C}$ signal did not show significant differences in this study (data not shown). Tillage treatment or fertilization did not significantly affect the MRT of corn-derived C in either the LF or the POM fractions.

\section{Bradford Reactive Soil Protein}

The Bradford reactive soil protein (glomalin) extracted with hot citrate comprised 1.6 to $2.5 \%$ of the SOC in the CT soils and 2.6 to $9.5 \%$ of the SOC in the NT soils at the time 
Table 8. Change in Bradford reactive soil protein (BRSP) content, its $\mathrm{C}$ derived from $\mathrm{C}_{4}$ residue inputs, and their mean residence time (MRT) initially and after 440 or $880 \mathrm{~d}$ of incubation of soils.

\begin{tabular}{|c|c|c|c|c|c|c|c|c|}
\hline \multirow[b]{2}{*}{ Site and treatment } & \multicolumn{4}{|c|}{ Conventional tillage } & \multicolumn{4}{|c|}{ No-till } \\
\hline & C & $\delta^{13} \mathrm{C}$ & $\begin{array}{c}C \text { from } \\
C_{4} \text { inputs }\end{array}$ & MRT & C & $\delta^{13} \mathrm{C}$ & $\begin{array}{c}C \text { from } \\
\mathrm{C}_{4} \text { inputs }\end{array}$ & MRT \\
\hline & $\mathrm{g} \mathrm{C} \mathrm{kg}^{-1}$ & $\%$ & $\%$ & $\mathrm{yr}$ & $\mathrm{g} \mathrm{C} \mathrm{kg}^{-1}$ & $\%$ & $\%$ & $\mathrm{yr}$ \\
\hline \multicolumn{9}{|l|}{ Wooster, $\mathrm{OH}$} \\
\hline Initial & $0.70(0.01) \dagger$ & $-19.8(0.3)$ & 42.2 & & $1.23(0.02)$ & $-20.9(0.3)$ & 34.1 & \\
\hline $440 \mathrm{~d}$ & $0.65(0.03)$ & $-21.7(0.1)$ & 28.2 & & $1.15(0.01)$ & $-21.0(0.4)$ & 33.3 & \\
\hline $800 \mathrm{~d}$ & $0.60(0.03)$ & $-21.5(0.2)$ & 29.6 & 42.8 & $0.79(0.03)$ & $-21.5(0.4)$ & 29.6 & 14.9 \\
\hline \multicolumn{9}{|l|}{ Hoytville, $\mathrm{OH}$} \\
\hline Initial & $2.14(0.3)$ & $-24.0(0.1)$ & 7.7 & & $5.36(1.3)$ & $-22.6(1.4)$ & 18.5 & \\
\hline $440 \mathrm{~d}$ & $2.03(0.4)$ & $-23.8(0.4)$ & 9.3 & & $2.33(0.2)$ & $-24.6(0.6)$ & 13.1 & \\
\hline $800 \mathrm{~d}$ & $2.00(0.5)$ & $-24.6(0.3)$ & 3.1 & 96.5 & $3.00(0.1)$ & $-23.2(0.2)$ & 13.9 & 11.3 \\
\hline \multicolumn{9}{|l|}{ Kellogg Biological Stn., MI } \\
\hline Initial & $0.73(0.2)$ & $-24.5(0.3)$ & 17.8 & & $0.74(0.01)$ & $-24.4(0.8)$ & 18.9 & \\
\hline $440 \mathrm{~d}$ & $0.77(0.04)$ & $-24.8(0.1)$ & 14.4 & & $0.59(0.01)$ & $-24.9(0.1)$ & 13.3 & \\
\hline \multirow[t]{2}{*}{$800 d$} & $0.63(0.1)$ & $-24.8(0.1)$ & 14.4 & 45.1 & $0.57(0.05)$ & $-25.1(0.1)$ & 11.1 & 25.4 \\
\hline & \multicolumn{4}{|c|}{$\underline{\text { Unfertilized }}$} & \multicolumn{4}{|c|}{$\underline{160 \mathrm{~N} \mathrm{~kg} \mathrm{ha}}=-1$} \\
\hline \multicolumn{9}{|l|}{ Lamberton, MN } \\
\hline Initial & $3.77(0.8)$ & $-18.2(0.1)$ & 17.3 & & $4.39(0.8)$ & $-17.9(0.4)$ & 21.3 & \\
\hline $440 \mathrm{~d}$ & $3.60(0.9)$ & $-18.6(0.3)$ & 12.0 & & $3.15(0.7)$ & $-17.3(0.5)$ & 29.3 & \\
\hline $800 \mathrm{~d}$ & $3.59(0.6)$ & $-18.5(0.3)$ & 13.3 & 104.5 & $2.82(0.5)$ & $-17.9(0.5)$ & 21.3 & 18.2 \\
\hline
\end{tabular}

of soil sampling (Table 8). Similar results were obtained from the Lamberton soils, which had a $\mathrm{N}$ fertilizer treatment rather than a CT-NT comparison. The proportion of BRSP derived from corn inputs, as determined by the ${ }^{13} \mathrm{C}$ contents, varied with soil type, in that the Wooster soil showed approximately one-third of the BRSP to be corn derived. The higher SOC Hoytville had $<10 \%$ of the BRSP as corn derived SOC after 30 yr of continuous CT corn, as evidenced by the ${ }^{13} \mathrm{C}$ contents of about $-24 \%$ relative to the total SOC of $-22 \%$. This indicates a very slow turnover rate of approximately $100 \mathrm{yr}$ in the field. The NT Hoytville soil had twice as much corn-derived BRSP-C and the amount of this material dropped from 9.6\% of the SOC to $2 \%$ during incubation in the NT soils. The Lamberton soils had similar percentages of BRSP in both treatments, but its ${ }^{13} \mathrm{C}$ content showed more corn-derived material in the $\mathrm{N}$ fertilizer treatment. This was not expected, as the literature indicates that $\mathrm{N}$ treatment should lower the arbuscular mycorrhizal fungi in this soil. The data agree with the observations of Nichols and Wright (2005), Schindler et al. (2007), and Rosier et al. (2006) that much of the material extracted by the hot citric acid has co-extracted constituents such as humic acids and other proteinaceous material. The anomaly in the NT Hoytville soil, however, merits further investigation.

\section{CONCLUSIONS}

The analysis of soils from long-term plots before and after laboratory incubation, in which the microbial enzymes were allowed to decompose the labile soil components, provided a great deal of useful information on physically separated fractions to complement the ${ }^{13} \mathrm{C}$ (Collins et al., 1999), ${ }^{14} \mathrm{C}$ (Paul et al., 2001), and incubation data (Collins et al., 2000) of our previous studies.

There continues to be a hope that physical fractions such as the LF and POM can be used as a directly measured fraction in modeling. The plant residues remaining in soil, as represented by the LF, were increased by NT. Their stability during incubation was not different under the two management systems nor was it site (soil) specific, showing that inherent chemical characteristics controlled turnover rates. Both the proportion of corn-derived $\mathrm{C}$, as sampled in the field after continuous corn, and the ${ }^{13} \mathrm{C}$ measurements during this incubation indicated that LF and POM fractions were not homogenous. Black $\mathrm{C}$ or charcoal found in both the LF and POM could be one explanation; however, the corn-derived $\mathrm{C}$ comes from the last $30 \mathrm{yr}$ of cultivation with no known history of fire and we believe that some factor other than, or in addition to, charcoal is responsible for approximately one-third of both the LF and POM that is much older than the rest.

The silt- and clay-associated C from corn was older than the LF and POM in all soils. In three soils, the clay-associated residues had the largest MRT. In one soil (Wooster), the silt-associated, corn-derived material had a longer MRT than the clay. The MRTs of the $\mathrm{C}_{3}-\mathrm{C}$, or non-corn-derived $\mathrm{C}$, in the silt and clay, as measured during incubation, are starting to approach but are still approximately one-quarter the values of the whole soil as measured by $\mathrm{C}$ dating. This study further shows that $\mathrm{SOM}$ is a continuum of materials from very young to very old with ongoing transfers between pools. A combination of physical, chemical, and biologically defined kinetic pools can help determine its dynamics, but the hope of straightforward direct fractionations will be fulfilled only with great difficulty because of the many interactions involved.

\section{ACKNOWLEDGMENTS}

This study was supported by a grant from the U.S. Department of Energy, Office of Research, DE-FGO3-00ER 66297 to E.A. Paul and by USDAARS CRIS no. 5354-21660-001-00D. The analysis was performed at the Dep. of Crop and Soil Sciences, Michigan State Univ., East Lansing. We wish to thank the Ohio State University for maintaining the plots from published research at Hoytville, OH, the Southwest Experiment Station, University of Minnesota, Lamberton, and the KBS NSF-LTER, Michigan State University, for sampling access to their long-term plots. Their 
foresight in maintaining such valuable scientific resources over the years is commendable and much appreciated.

\section{REFERENCES}

Anderson, D.A., and E.A. Paul. 1984. Organo-mineral complexes and their study by radiocarbon dating. Soil Sci. Soc. Am. J. 48:298-301.

Anderson, D.W., S. Saggar, J.R. Bettany, and J.W.B. Stewart. 1981. Particle-size fractions, and their use in studies of soil organic matter: I. The nature and distribution of forms of carbon, nitrogen, and sulfur. Soil Sci. Soc. Am. J. 45:767-772.

Balesdent, J., and M. Balabane. 1992. Maize root-derived soil organic carbon estimated natural ${ }^{13} \mathrm{C}$ abundance. Soil Biol. Biochem. 24:97-101.

Balesdent, J., A. Mariotti, and B. Guillet. 1987. Natural ${ }^{13} \mathrm{C}$ abundance as a tracer for studies of soil organic matter dynamics. Soil Biol. Biochem. 19:25-30.

Balesdent, J., G.H. Wagner, and A. Mariotti. 1988. Soil organic matter turnover in long-term field experiments as revealed by carbon-13 natural abundance. Soil Sci. Soc. Am. J. 52:118-124.

Beare, M.H., P.F. Hendrix, and D.C. Coleman. 1994. Water stable aggregates and organic matter fractions in conventional- and no-tillage soils. Soil Sci. Soc. Am. J. 58:777-786.

Boutton, T.W. 1996. Stable carbon isotope ratios of soil organic matter and their use as indicators of vegetation and climate change. Marcel Dekker, New York.

Buyanovsky, G.A., M. Aslam, and G.H. Wagner. 1994. Carbon turnover in soil physical fractions. Soil Sci. Soc. Am. J. 58:1167-1173.

Cambardella, C.A., and E.T. Elliott. 1992. Particulate soil organic matter changes across a grassland cultivation sequence. Soil Sci. Soc. Am. J. 56:777-783.

Campbell, C.A., E.A. Paul, D.A. Rennie, and K.J. McCallum. 1967a. Factors affecting the accuracy of the carbon dating method of soil humus studies. Soil Sci. 104:81-85.

Campbell, C.A., E.A. Paul, D.A. Rennie, and K.J. McCallum. 1967b. Applicability of the carbon dating method to soil humus studies. Soil Sci. 104:217-224.

Christensen, B.T. 1987. Decomposability of organic matter in particle size fractions from field soils with straw incorporation. Soil Biol. Biochem. 19:429-435.

Christensen, B.T. 1992. Physical fractionation of soil and organic matter in primary particle size and density separates. Adv. Soil Sci. 20:1-90.

Christensen, B.T., and L.H. Sorensen. 1985. The distribution of native and labeled carbon between soil particle size fractions isolated from longterm incubation experiments. J. Soil Sci. 36:219-229.

Collins, H.P., L.G. Bundy, D.R. Christenson, W.A. Dick, D.R. Huggins, and E.A. Paul. 1999. Soil carbon dynamics in corn-based agroecosystems: Results from carbon-13 natural abundance. Soil Sci. Soc. Am. J. 63:584-591.

Collins, H.P., L.G. Bundy, W.A. Dick, D.R. Huggins, A.J.M. Smucker, and E.A. Paul. 2000. Soil carbon pools and fluxes in long-term Corn Belt agroecosystems. Soil Biol. Biochem. 32:157-168.

Dalal, R.C., and R.J. Mayer. 1986a. Long-term trends in fertility of soils under continuous cultivation and cereal cropping in South Queensland: III. Distribution and kinetics of soil organic carbon in particle-size fractions. Aust. J. Soil Res. 24:293-300.

Dalal, R.C., and R.J. Mayer. 1986b. Long-term trends in fertility of soils under continuous cultivation and cereal cropping in South Queensland: IV. Loss of organic carbon from different density fractions. Aust. J. Soil Res. 24:301-309.

Flach, K.W., T.O. Barnwell, Jr., and P. Crosson. 1997. Impacts of agriculture on atmospheric carbon dioxide. CRC Press, Boca Raton, FL.

Goldchin, A., J.M. Oades, J.O. Skjemstad, and P. Clarke. 1995. Structural and dynamic properties of soil organic matter as reflected by ${ }^{13} \mathrm{C}$ abundance, pyrolysis mass spectrometry and solid state ${ }^{13} \mathrm{C}$ NMR spectroscopy in density fractions of an Oxisol under forest and pasture. Aust. J. Soil Res. 33:59-76.

Greenland, D.J., and G.W. Ford. 1964. Separation of partially humified organic materials from soils by ultrasonic dispersion. p. 137-148. In
Trans. Int. Congr. Soil Sci., 8th, Bucharest, Romania. Vol. 3. ISSS, Wageningen, the Netherlands.

Gregorich, E.G., C.F. Drury, B.H. Ellert, and B.C. Liang. 1997. Fertilization effects on physically protected light fraction organic matter. Soil Sci. Soc. Am. J. 61:482-484.

Gregorich, E.G., B.H. Ellert, and C.M. Monreal. 1995. Turnover of soil organic matter and storage of corn residue carbon estimated from natural ${ }^{13} \mathrm{C}$ abundance. Can. J. Soil Sci. 75:161-167.

Haile-Mariam, S., W. Cheng, D.W. Hohnson, J.T. Ball, and E.A. Paul. 2000. Use of carbon-13 and carbon-14 to measure the effects of carbon dioxide and nitrogen fertilization on carbon dynamics in ponderosa pine. Soil Sci. Soc. Am. J. 64:1984-1993.

Janzen, H.H., C.A. Cambell, S.A. Brandt, G.P. Lafond, and L. TownleySmith. 1992. Light-fraction organic matter in soils from long-term crop rotations. Soil Sci. Soc. Am. J. 56:1799-1806.

Martel, Y., and E.A. Paul. 1974. Effects of cultivation on the organic matter of grassland soils as determined by fractionation and carbon dating. Can. J. Soil Sci. 54:419-426.

Nichols, K.A., and S.F. Wright. 2005. Comparison of glomalin and humic acid in eight native U.S. soils. Soil Sci. 170:985-987.

Paul, E.A., H.P. Collins, and S.W. Leavitt. 2001. Dynamics of resistant soil carbon of Midwestern agricultural soils measured by naturally occurring ${ }^{14} \mathrm{C}$ abundance. Geoderma 104:239-256.

Paustian, K., H.P. Collins, and E.A. Paul. 1997. Management controls on soil carbon. CRC Press, Boca Raton, FL.

Rillig, M.C., P.W. Ramsey, S.J. Morris, and E.A. Paul. 2003. Glomalin, an arbuscular-mycorrhizal fungal soil protein, responds to land-use change. Plant Soil 253:299-303.

Rosier, C.L., A.T. Hoye, and M.T. Rillig. 2006. Glomalin related soil protein: Assessment of current detection and quantification tools. Soil Biol. Biochem. 38:2205-2211.

Schindler, F.V., E.J. Mercer, and J.A. Rice. 2007. Chemical characterization of glomalin-related soil protein (GRSP) extracted from soils of various organic matter contents. Soil Biol. Biochem. 39:320-329.

Six, J., E.T. Elliott, K. Paustian, and J.W. Doran. 1998. Aggregation and soil organic matter accumulation in cultivated and native grassland soils. Soil Sci. Soc. Am. J. 62:1367-1377.

Skjemstad, J.P., R.C. Dalal, and P.F. Barron. 1986. Spectroscopic investigations of cultivation effects on organic matter of Vertisols. Soil Sci. Soc. Am. J. 50:354-359.

Smith, S.J., and L.B. Young. 1975. Distribution of nitrogen forms in virgin and cultivated soils. Soil Sci. 120:354-360.

Sohi, S.P., N. Mahieu, D.S. Powlson, B. Madari, R.H. Smittenberg, and J.L. Gaunt. 2005. Investigating the chemical characteristics of soil organic matter fractions suitable for modeling. Soil Sci. Soc. Am. J. 69:1248-1255.

Sollins, P., C. Swanston, M. Kleber, T. Filley, M. Kramer, S. Crow, B.A. Caldwell, K. Lajtha, and R. Bowden. 2006. Organic C and N stabilization in a forest soil: Evidence from sequential density fractionation. Soil Biol. Biochem. 38:313-324.

Sorensen, L.H. 1972. Stabilization of newly formed amino acid metabolites in the formation of soil organic matter. Soil Sci. 114:5-11.

Steinberg, P.D., and M.C. Rillig. 2003. Differential decomposition of arbuscular mycorrhizal fungal hyphae and glomalin. Soil Biol. Biochem. 35:191-194.

Stevenson, F.J., and A.P.S. Dhariwal. 1959. Distribution of fixed ammonium in soils. Soil Sci. Soc. Am. Proc. 23:121-125.

Stevenson, F.J., and E.T. Elliott. 1989. Methodologies for assessing the quantity of soil organic matter. p. 173-199. In D.C. Coleman et al. (ed.) Dynamics of soil organic matter in tropical ecosystems. Niftal Project, Univ. of Hawaii Press, Honolulu.

Tiessen, H., and J.W.B. Stewart. 1983. Particle-size fractions and their use in studies of soil organic matter: II. Cultivation effects on organic matter composition in size fractions. Soil Sci. Soc. Am. J. 47:509-514.

Wright, S.F., and A. Upadhyaya. 1996. Extraction of an abundant and unusual protein from soil and comparison with hyphal protein of arbuscular mycorrhizal fungi. Soil Sci. 161:575-586. 